Research Paper

\title{
Eifect of Bone Morphogenetic Protein-2 on Proliferation and Apoptosis of Gastric Cancer Cells
}

\author{
Junjie Zhang\#, Yanli Ge”, Longe Sun\#, Jianchun Cao, Qiong Wu, Likun Guo, Zhirong Wang ${ }^{\bowtie}$ \\ Department of Gastroenterology, Tongji Hospital, Tongji University, Shanghai 200065, China \\ \#Contributed equally.
}

$\triangle$ Corresponding author: Zhirong Wang, Tel:+8621-66111329; Email: docwangwang@yeah.net

(c) Ivyspring International Publisher. This is an open-access article distributed under the terms of the Creative Commons License (http://creativecommons.org/ licenses/by-nc-nd/3.0/). Reproduction is permitted for personal, noncommercial use, provided that the article is in whole, unmodified, and properly cited.

Received: 2011.11.23; Accepted: 2012.02.08; Published: 2012.02.15

\begin{abstract}
Objective: To investigate the effects of bone morphogenetic protein-2 (BMP-2) on the proliferation, differentiation and apoptosis of normal human gastric mucosal cells and gastric cancer cells.

Methods: Poorly differentiated gastric cancer BGC823 cells, moderately differentiated gastric cancer cells and normal human gastric mucosal epithelial GES-I cells were independently treated with recombinant human BMP-2 or its inhibitor Noggin. MTT assay was performed to detect the proliferation, flow cytometry done to measure the cell cycle and apoptosis and immunohistochemistry carried out to determine the expression of cyclin-dependent kinase 4 (CDK4).

Results: BMP-2 exerted inhibitory effect on the growth of all types of cells and the inhibition become more evident with the increase of BMP-2 dose. After treatment with $200 \mathrm{ng} / \mathrm{ml} \mathrm{BMP-2,}$ cancer cells arrested in GI phase and those in $S$ phase reduced. Gastric cancer cells had higher CDK4 expression than GES-I cells. BMP-2 decreased CDK-4 expression in cancer cells but had no influence in GES-I cells. Noggin conferred promotive effect on the growth of 3 types of cells. In 2 types of cancer cells, treatment with $2000 \mathrm{ng} / \mathrm{ml}$ Noggin significantly increased the proportion of cells in S phase but reduced that in GI phase. However, Noggin did not affect the cell cycle of GES-I cells. The CDK4 expression was markedly increased in 2 types of cancer cells but that of GES-I remained unchanged after treatment with $2000 \mathrm{ng} / \mathrm{ml}$ Noggin.

Conclusions: BMP-2 may inhibit the proliferation of both normal and malignant gastric epithelial cells, down-regulate CDK4 expression in gastric cancer cells and arrest gastric cancer cells in GI-phase in cell cycle. Through antagonizing BMP-2, Noggin, may accelerate the proliferation of gastric cancer cells. Thus, the abnormality of BMP signaling pathway may play an important role in the pathogenesis of gastric cancer.
\end{abstract}

Key words: Bone morphogenetic protein 2; Noggin; gastric cancer cell; proliferation; cell cycle; apoptosis; cyclin-dependent kinase 4

\section{Introduction}

Gastric cancer is a malignancy derived from the gastric mucosal epithelial cells and accounts for 95\% of gastric malignancies. Gastric cancer has become a common malignancy threatening the human health. Thus, to elucidate the pathogenesis has been a focus in gastrointestinal research. Loss of response to signals for cell growth plays a pivotal role in the occurrence and development of tumors. Cytokines function to regulate cell growth usually in the G1 phase, and cells transiting G1 phase are seldom regulated by signals 
for cell growth. Among numerous cytokines, transforming growth factor (TGF- $\beta$ ) can inhibit the growth of cells in this phase.

TGF- $\beta$ is a secretory polypeptide superfamily and includes TGF- $\beta$, activin, bone morphogenetic proteins (BMPs), etc. To date, a variety of studies have been conducted to investigate the role of TGF- $\beta$ in the pathogenesis of gastric cancer. There is evidence showing that TGF- $\beta 1$ plays crucial roles in the differentiation and proliferation of gastric cancer cells [1]. The poorer the differentiation of gastric cancer is, the higher the TGF- $\beta$ expression is. The effect of TGF- $\beta$ on the cell proliferation is mediated by the receptors on the cell surface.

BMPs belong to TGF- $\beta$ superfamily and distributed in numerous tissues and cells of human body. The signals induced by BMPs are mediated by the receptors on the target cells and transit into cells to exert effect [2-4]. The relationship between BMP and gastrointestinal diseases has been a focus in studies on gastrointestinal medicine. BMP signal transduction may play crucial role in the differentiation of intestinal mucosal cells and can maintain the phenotype of epithelial cells [5]. Bone morphogenetic protein-2 (BMP-2) is a member of TGF- $\beta$ superfamily and was firstly found to induce the ectopic osteogenesis [6]. BMPs play important roles in the embryonic development and differentiation and proliferation of tissues and cells. Different BMPs can exert distinct effects, which contribute to the cell type, stage of cell differentiation and the presence of other cytokines [7]. In the development of fetal rats, BMP-4 is expressed in the mesenchymal cells in villi. In addition, normal colon mucosa of human and adult rats, BMP-4 expression is also noted in the epithelial cells in the stage of differentiation and maturation [8]. Hardwick et al found that BMP-2 could inhibit the growth of colonic epithelial cells, promote their apoptosis and inhibit their proliferation in vivo, and expressions of BMP-2, BMPR IA, BMPR IB and phosphorylated Smad 1/4 were found on colonic epithelial cells of human and mouse. However, in patients with familial adenomatous polyposis, the BMP-2 expression was significantly reduced in the microglands [9]. Studies have demonstrated that BMP-2 and BMP-6 can accelerate the apoptosis of cells in myeloblastoma, multiple myeloma and renal carcinoma [10-12]. As compared to normal lung tissues, BMP-2 is highly expressed in $98 \%$ of lung cancer [13]. Currently, the role of BMPs in the pathogenesis of tumors is still unclear. Previous in vivo and in vitro studies showed BMP-2/4 was related to the invasion and metastasis of cancer cells, and could promote the metastasis of prostate cancer and melanoma [14-16] and stimulate the proliferation of bladder cancer cells [17]. In prostate cancer patients with bone metastasis, the BMP-7 expression was markedly increased [18]. Aoki et al found that the positive rate of BMP-7 was about $55 \%$ in 233 gastric cancer patients [19]. Katoh et al for the first time reported the protein and mRNA expressions of BMP-2 in human gastric cancer cells [20]. Kim et al indicated that the BMP-4 expression in gastric cancer patients was dramatically higher than that in healthy controls and BMP-4 expression was negatively associated with the lymph node metastasis of gastric cancer, which suggests BMP-4 might involve in the occurrence and metastasis of gastric cancer [21]. In our previous study, histological examination showed the BMP-2 expression had a decreasing trend in the progression of chronic inflammation of gastrointestinal mucosa into atypical hyperplasia/intestinal metaplasia (precancerous lesion) and gastric cancer [22, 23]. This implies that BMP-2 might be related with the biological behaviors of gastric mucosal epithelial cells. However, the role of BMP-2 in the proliferation and apoptosis of normal gastric mucosal cells and human gastric cancer cells is still poorly understood.

In the present study, normal gastric mucosal cells (GES-1) and gastric cancer cells (poorly differentiated BGC823 cells and moderately differentiated SGC7901 cells) were treated with recombinant human BMP-2 (rhBMP-2) or its inhibitor (Noggin) and MTT assay, flow cytometry and immunocytochemistry were performed to detect the cell proliferation, cell cycle and cyclin-dependent kinase aiming to investigate the role of BMP-2 in the pathogenesis of gastric cancer.

\section{Materials and methods}

\section{Cell lines and culture}

BGC823 cells and SGC7901 cells were purchased from the Shanghai Institute of Cytobiology in Chinese Academy of Sciences and GES-1 cells from the Institute of Oncology in Beijing University. These cells were maintained in DMEM (Gibco) containing 10\% fetal bovine serum (Hangzhou Sijiqing Biotech) at $37^{\circ} \mathrm{C}$ in a humidified atmosphere with $5 \% \mathrm{CO}_{2}$. Passaging was performed every $72 \mathrm{~h}$. Cells in logarithmic phase were then digested with $0.25 \%$ trypsin and washed in PBS. Cell suspension of designed concentration was prepared with DMEM.

\section{Detection of cell proliferation by MTT assay}

Cells in logarithmic phase were digested in trypin and $4 \times 10^{4} / \mathrm{ml}$ cell suspension was prepared. These cells were seeded into 96-well plate (150 $\mu \mathrm{l} /$ well) and 6 wells in each group. Three types of 
cells were independently 2 groups: rhBMP-2 (R\&D) group and Noggin (PeproTechEC) group. In each group, cells were subdivided into 3 subgroups: blank control group, cell control group and treatment group. In the rhBMP-2 group, cells were treated with rhBMP-2 at $50 \mathrm{ng} / \mathrm{ml}, 100 \mathrm{ng} / \mathrm{ml}$ and $200 \mathrm{ng} / \mathrm{ml}$. In the Noggin group, cells were treated with Noggin at 1 $\mathrm{ng} / \mathrm{ml}, 10 \mathrm{ng} / \mathrm{ml}, 100 \mathrm{ng} / \mathrm{ml}, 1000 \mathrm{ng} / \mathrm{ml}$ and 2000 $\mathrm{ng} / \mathrm{ml}$. Cells were maintained for $24 \mathrm{~h}$. When cell adhesion was present, the culture medium was removed and then $150 \mu \mathrm{l}$ of rhBMP-2/Noggin at different concentrations were added to each well and culture medium of equal volume was added to control groups. At 24, 48 and $72 \mathrm{~h}$ after treatment, cell proliferation was determined. At $4 \mathrm{~h}$ before treatment, $20 \mu \mathrm{l}$ of MTT solution (Sigma) was added to each well followed by incubation for $4 \mathrm{~h}$. After removal of medium, $150 \mu \mathrm{l}$ of DMSO were supplemented followed by shaking for $10 \mathrm{~min}$. Blank control group was also set for zero adjustment. Absorbance (A) was measured at $570 \mathrm{~nm}$ and inhibition rate (IR) was calculated as follow: $I R=\left(A_{\text {control }}-A_{\text {experiment }}\right) / A_{\text {control }} \times 100 \%$.

\section{Detection of cell cycle by flow cytometry}

Cells in logarithmic phase were digested in trypin and cell suspension was prepared. These cells were seeded into 6 -well plate $\left(2 \times 10^{5} /\right.$ well $)$ and 3 wells in each group. Grouping was identical to that above but $200 \mathrm{ng} / \mathrm{ml} \mathrm{rhBMP}-2$ and $2000 \mathrm{ng} / \mathrm{ml}$ Noggin were used for treatment. When cell adhesion was present, culture medium in each well was removed. Then, $3 \mathrm{ml}$ of rhBMP-2/ Noggin was added to each well and culture medium of equal volume supplemented into wells in the control group followed by incubation. At $48 \mathrm{~h}$ after incubation, cells were collected by centrifugation (3000 rpm/min for $5 \mathrm{~min}$ ) and washed in PBS (pH: 7.4). The supernatant was slowly removed and cells were re-suspended in $1 \mathrm{ml}$ of cold PBS followed by centrifugation at $3000 \mathrm{rpm} / \mathrm{min}$ for $5 \mathrm{~min}$. Then, $200 \mu$ of cold PBS were used for re-suspension of cells followed by addition of $70 \%$ cold alcohol and subsequent incubation at $4^{\circ} \mathrm{C}$ overnight. The supernatant was removed by centrifugation and cells were re-suspended in $1 \mathrm{ml}$ of cold PBS followed by centrifugation. PI working solution (Kagene Biotech Co., Ltd) was added followed by incubation at $37^{\circ} \mathrm{C}$ for 30 min. Flow cytometry was performed at an exciting wavelength of $488 \mathrm{~nm}$.

\section{Detection of apoptosis by flow cytometry}

After rhBMP-2 treatment, apoptosis of 3 types of cells was determined by flow cytometry. Grouping was similar to that above. Cells were incubated for 48 $\mathrm{h}$ and then digested in EDTA containing trypsin solu- tion. Cells were collected and washed in PBS (pH: 7.4) twice followed by centrifugation at $300 \mathrm{rpm}$ for $5 \mathrm{~min}$. Cells were collected and then re-suspended in $500 \mu \mathrm{l}$ of binding buffer followed by addition of $5 \mu$ of AnnexinV-FITC and $5 \mu \mathrm{l}$ of Propidium Iodide (Kagene Biotech Co., Ltd). Incubation was performed in dark at room temperature for $10 \mathrm{~min}$ followed by flow cytometry. In the scatter plot, left lower quadrant represents viable cells, right upper quadrant represents cells at middle or late apoptosis phase and necrotic cells and right lower quadrant represent cells at early apoptosis phase.

\section{Detection of CDK4 by immunocytochemistry}

The coverslips were treated with concentrated sulfuric acid overnight and then washed in flowing water and distilled water thrice. After drying and sterilization, these coverslips were placed into 24-well plate. Cells in logarithmic phase were digested in trypsin solution and $6 \times 10^{4} / \mathrm{ml}$ cell suspension was prepared. These cells were then seeded into 24-well plate. Cells were treated with rhBMP-2 or Noggin. When cell were adherent to the coverslip, the culture medium was removed and $2 \mathrm{ml}$ of $200 \mathrm{ng} / \mathrm{ml}$ rhBMP-2 / $2000 \mathrm{ng} / \mathrm{ml}$ Noggin were added into each well. In the control group, culture medium of equal volume was supplemented. Incubation was performed for $72 \mathrm{~h}$ and coverslips were collected followed by detection with a SABC kit (Wuhan Boster Biotech Co., Ltd) according to manufacturer's instructions. In brief, the coverslips were washed in PBS (pH: 7.4) thrice and then fixed in $4 \%$ formaldehyde for 15 min. After washing in PBS thrice, coverslips were treated with hydrogen peroxide solution (30\% hydrogen peroxide: formaldehyde $=1: 50$ ) at room temperature for $30 \mathrm{~min}$ to inactivate endogenous peroxydase. Then, the coverslips were washed in distilled water twice and treated with normal goat serum for blocking at room temperature for $20 \mathrm{~min}$. The liquid on the coverslips was removed and they were incubated with rabbit anti-human CDK4 polyclonal antibody (Wuhan Boster Biotech Co., Ltd) at $4{ }^{\circ} \mathrm{C}$ overnight. In the negative control group, the primary antibody was replaced with PBS. After washing in PBS thrice (2 min for each), the coverslips were treated with biotin-conjugated goat anti-rabbit $\operatorname{IgG}$ at $37^{\circ} \mathrm{C}$ for $60 \mathrm{~min}$. Following washing in PBS thrice (2 min for each), the coverslips were treated with $\mathrm{SABC}$ at $37^{\circ} \mathrm{C}$ for $20 \mathrm{~min}$ followed by washing in PBS 4 times (5 min for each). DAB (Wuhan Boster Biotech Co., Ltd) was employed for visualization at room temperature. After washing in distilled water, dehydration, transparentization and mounting, the cells on the coverslips were observed under a light microscope. 
CDK4 was mainly expressed in the nucleus and positive cells had brown nucleus. Five fields were randomly selected at high magnification (395568.00 $\mathrm{um} /$ field) and the percentage of area with positive cells was determined.

\section{Statistical analysis}

Data were expressed as means \pm standard deviation (means \pm SD) and SPSS version 13.0 software program was employed for statistical analysis. Analysis of variance was employed for the analysis of proliferation of gastric cancer cells and epithelial cells of normal gastric mucosa following treatment with BMP-2 and/or Noggin. T test was performed for the analysis of cell cycle and CDK4 expression following treatment with BMP-2 and/or Noggin.

\section{Results}

\section{Effects of BMP-2 and Noggin on the prolifera- tion of BGC823 cells, SGC790 I cells and GES-I cells}

When compared with control group, treatment with rhBMP-2 at different concentrations significantly inhibit the growth of three types of cells $(\mathrm{P}<0.05)$. In addition, the IR increased with the increase of rhBMP-2 concentration. At different time points, the proliferation of three types of cells following rhBMP-2 treatment was dramatically different from that in the control group $(\mathrm{P}<0.05)$. rhBMP-2 at lower than 100 $\mathrm{ng} / \mathrm{ml}$ had little influence on GES-1 cells within $24 \mathrm{~h}$, but the growth of GES-1 cells were markedly inhibited at $48 \mathrm{~h}$ and $72 \mathrm{~h}$. Noggin could promote the proliferation of three types of cells. When the Noggin concentration was $\geq 1000 \mathrm{ng} / \mathrm{ml}$, the proliferation did not increase with the increase of Noggin concentration $(\mathrm{P}>0.05)$. The most obvious proliferation was found at $48 \mathrm{~h}$ after Noggin treatment and the IR reduced with the prolongation of Noggin treatment. Additionally, the promotive effect of Noggin on the proliferation of BGC823 cells was more obvious than that on the proliferation of SGC7901 cells and GES-1 cells $(\mathrm{P}<0.05)$ (Figure 1 and 2).

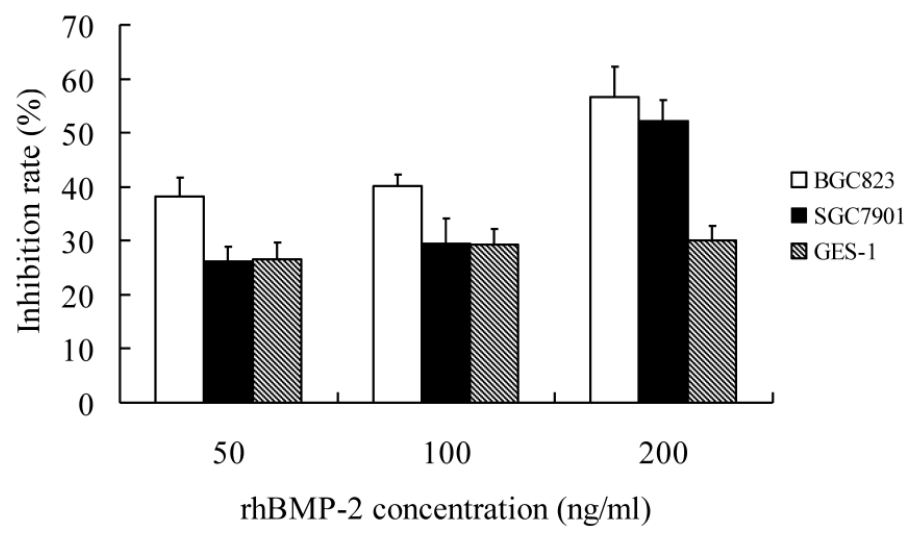

Figure I Effect of rhBmp-2 at different concentrations on the proliferation of different cells at $48 \mathrm{~h}$ after treatment.

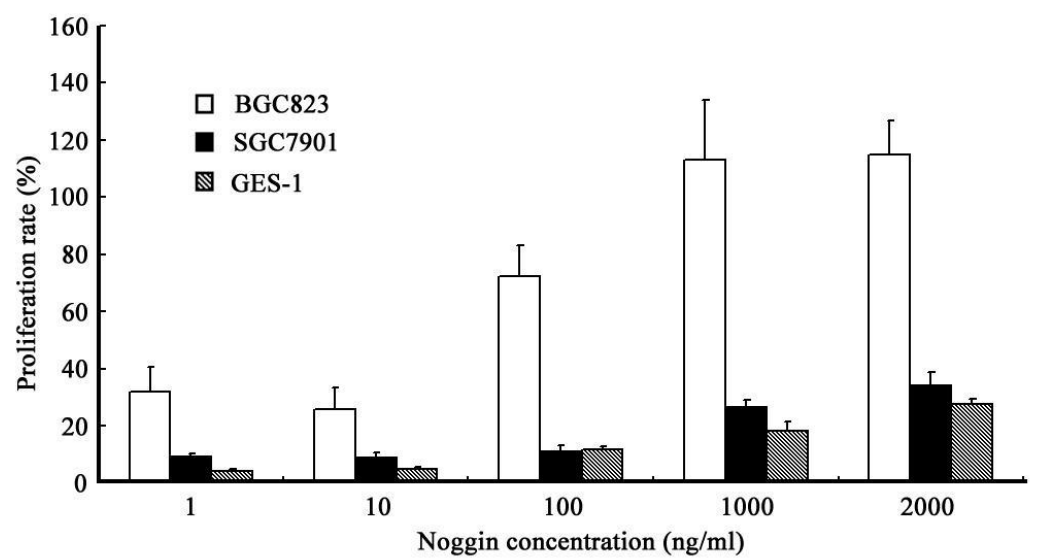

Figure 2 Effect of Noggin at different concentrations on the proliferation of different cells at $48 \mathrm{~h}$ after treatment. 


\section{Effects of BMP-2 and Noggin on the cell cycle and apoptosis of cells}

The rhBMP-2 treatment was performed for $48 \mathrm{~h}$ and cells were collected for flow cytometry. Results showed the proportion of BGC823 cells and SGC7901 cells in the G1 phase was significantly increased $(\mathrm{P}<0.05)$ but that in the $S$ phase dramatically reduced $(\mathrm{P}<0.05)$. Proportion of cells in the G2 phase remained unchanged. These findings suggested most cells were arrested in the G1 phase. After Noggin treatment for $48 \mathrm{~h}$, cells were collected for flow cytometry. Results showed the proportion of BGC823 cells and SGC7901 cells in the $S$ phase was markedly increased $(\mathrm{P}<0.05)$ but that in the G1 phase reduced dramatically $(\mathrm{P}<0.05)$. Proportion of cells in the G2 phase remained unchanged. These findings suggested Noggin increased the DNA synthesis in these cells. Of note, the proportion of GES-1 cells in the S phase and G1 phase remained unchanged following treatment with rhBMP-2/Noggin $(\mathrm{P}>0.05)$ (Table 1 and 2). Three types of cells were treated with $200 \mathrm{ng} / \mathrm{ml} \mathrm{BMP-2}$ for $72 \mathrm{~h}$ followed by flow cytometry. Results showed the proportion of different cells in early apoptosis phase remained unchanged after BMP-2 treatment.

\section{Effects of BMP-2 and Noggin on the CDK4 expression in BGC823 cells, SGC790 I cells and GES-I cells}

CDK4 expression was found in 3 types of cells. The CDK4 expression in BGC823 cells $(5.00 \pm 1.16)$ and BGC7901 cells $(4.06 \pm 0.99)$ was higher than that in GES- 1 cells $(2.82 \pm 0.67, \mathrm{P}<0.05)$. In addition, the CDK4 expression in BGC823 cells was significantly higher than that in BGC7901 cells. When compared with control group, after rhBMP-2 treatment, the CDK4 expression in BGC823 cells and SGC7901 cells was markedly reduced $(2.38 \pm 0.99$ vs $5.00 \pm 1.16$; $2.19 \pm 0.80$ vs $4.06 \pm 0.99 ; \mathrm{P}<0.05)$. After Noggin treatment, the CDK4 expression in BGC823 cells and SGC7901 cells was dramatically increased $(2.73 \pm 0.73$ vs $4.46 \pm 0.96 ; 2.04 \pm 0.90$ vs $3.66 \pm 0.75, P<0.05)$. In GES- 1 cells, the CDK4 expression remained unchanged after treatment with rhBMP-2/Noggin $(\mathrm{P}>0.05)$ (Figure 3 and 4).

\section{Discussion}

TGF- $\beta$ family is composed of some polypeptide growth factors with similar structure and functions and includes TGF- $\beta$, activin, BMPs, etc. TGF- $\beta$ not only can affect the proliferation and differentiation of some types of cells, but plays important roles in the embryonic development, formation of extracellular matrix, suppression of immune and inflammation, osteogenesis and bone re-construction. For epithelial cells, TGF- $\beta$ can block the transition from G1 phase to $S$ phase leading to cell growth arrest [24]. To date, numerous studies have demonstrated that the TGF- $\beta 1$ expression is significantly increased in cancer tissues and plasma of gastric cancer patients, which suggests TGF- $\beta 1$ is closely related to the occurrence of gastric cancer [25].

Table I Cell cycle of 3 types of cells before and after $200 \mathrm{ng} / \mathrm{ml} \mathrm{rhBmp}-2$ treatment (means \pm SD)

\begin{tabular}{lllllll}
\hline rhBmp-2 & G1 phase (\%) & \multicolumn{5}{c}{ S phase (\%) } \\
\hline & BGC823 & SGC7901 & GES-1 & BGC823 & SGC7901 & GES-1 \\
\hline- & $52.70 \pm 5.01$ & $43.30 \pm 2.75$ & $60.50 \pm 4.53$ & $38.50 \pm 1.48$ & $32.80 \pm 2.22$ & $29.40 \pm 2.80$ \\
+ & $61.60 \pm 2.75^{*}$ & $49.00 \pm 2.68^{*}$ & $60.40 \pm 3.00$ & $29.60 \pm 2.15^{*}$ & $28.20 \pm 2.37^{*}$ & $30.00 \pm 1.79$ \\
\hline
\end{tabular}

* $\mathrm{P}<0.05$ vs control group

Table 2 Cell cycle of 3 types of cells before and after $2000 \mathrm{ng} / \mathrm{ml}$ Noggin treatment (means \pm SD)

\begin{tabular}{lllllll}
\hline Noggin & G1 phase (\%) & \multicolumn{5}{l}{ S phase (\%) } \\
\hline & BGC823 & SGC7901 & GES-1 & BGC823 & SGC7901 & GES-1 \\
\hline- & $51.7 \pm 2.75$ & $52.2 \pm 3.73$ & $60.50 \pm 6.80$ & $39.50 \pm 4.78$ & $37.3 \pm 2.98$ & $29.40 \pm 3.43$ \\
+ & $40.20 \pm 2.68^{*}$ & $43.1 \pm 2.37^{*}$ & $60.40 \pm 5.28$ & $49.6 \pm 3.75^{*}$ & $47.4 \pm 2.95^{*}$ & $30.0 \pm 3.90$ \\
\hline
\end{tabular}

* $\mathrm{P}<0.05$ vs control group 

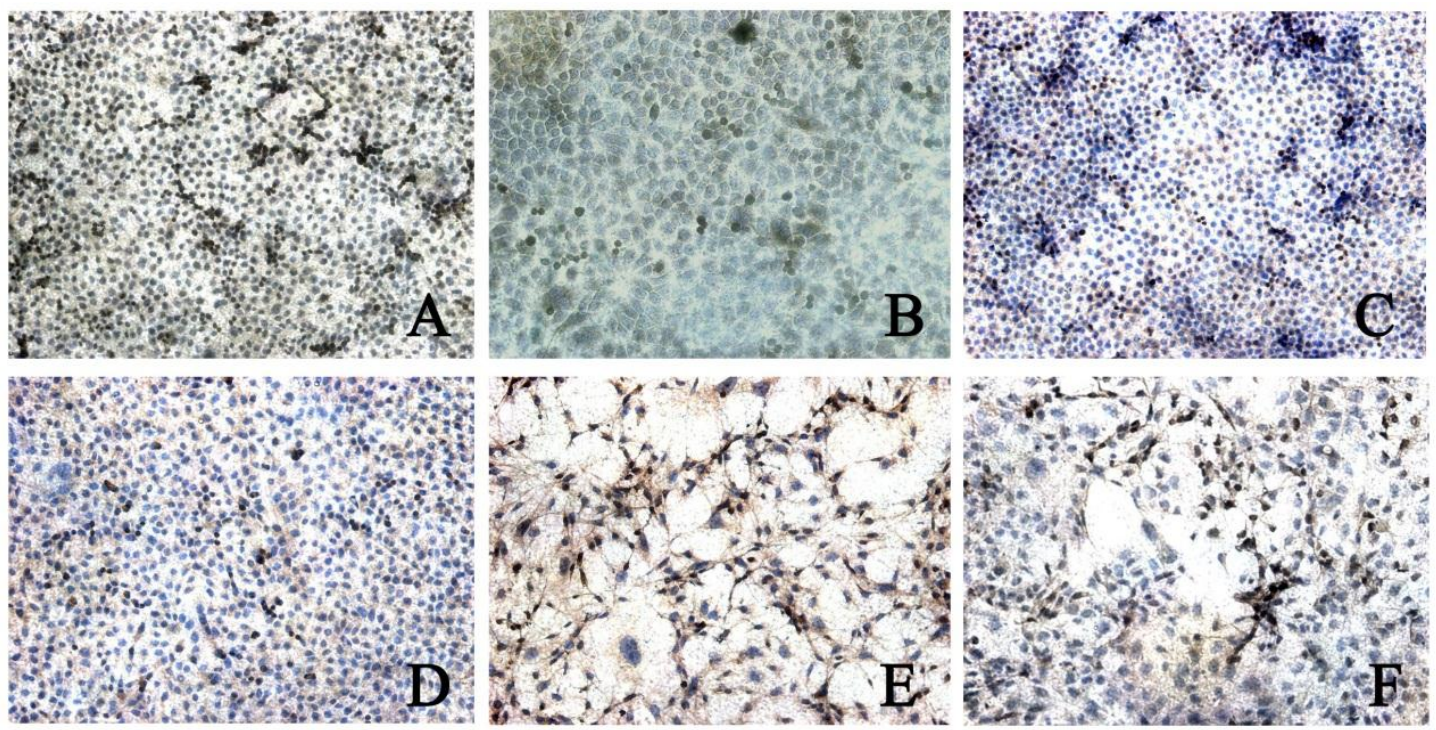

Figure 3 CDK 4 expression in different cells after rhBMP-2 treatment. Control group: A: BGC823 cells; C: SGC790I cells; E: GES-I cells; rhBMP-2 treatment: B: BGC823 cells; D: SGC790I cells; F: GES-I cells. $(\times 100)$
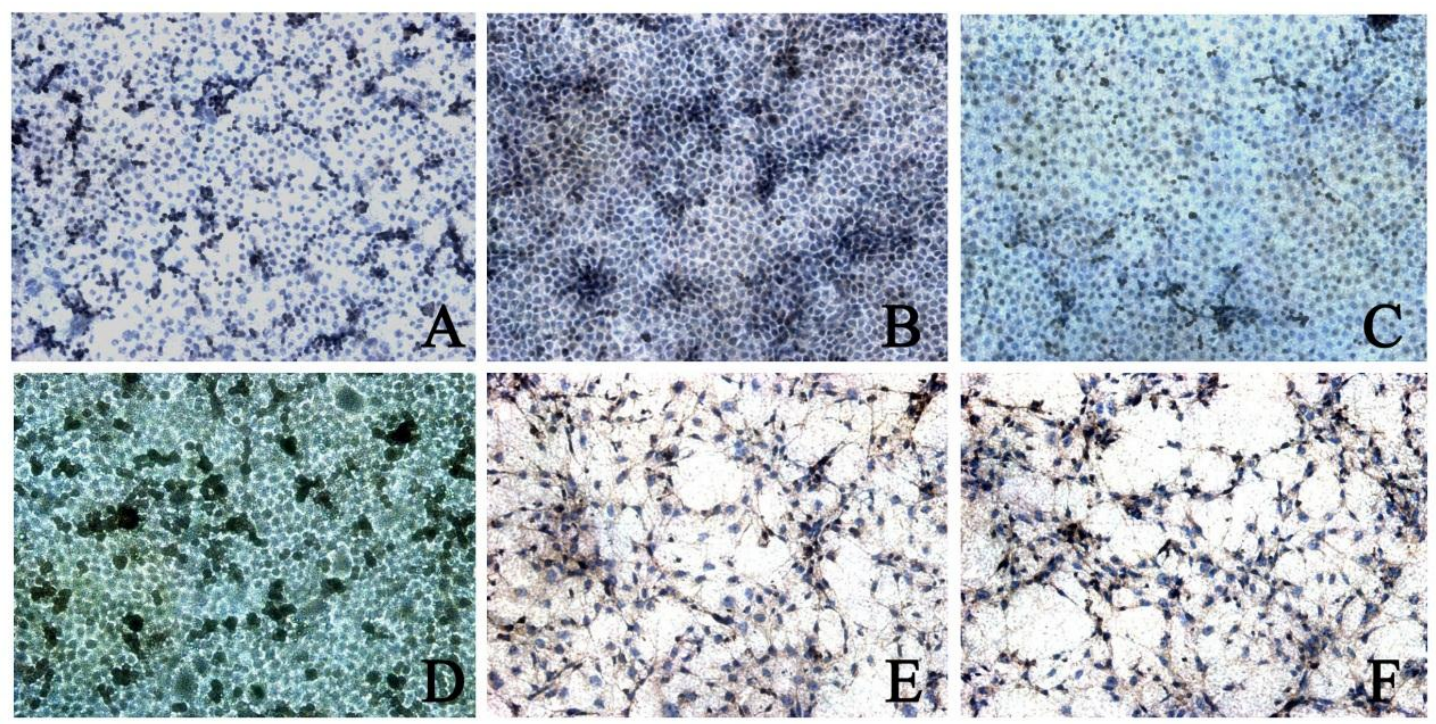

Figure 4 CDK4 expression in different cells after Noggin treatment. Control group: A: BGC823 cells; C: SGC790I cells; E: GES-I cells; rhBMP-2 treatment: B: BGC823 cells; D: SGC790I cells; F: GES-I cells. $(\times 100)$

BMPs are a member of TGF- $\beta$ superfamily and a dimmer consisting of two identical or different subunits. The homodimer functions via the p38 mitogen-activated protein kinase (MAPK) signaling pathway, but heterodimer involves in the Smad signal transduction [7]. BMPs can promote the differentiation of epithelial cells and suppression of BMP-related signal transduction has been found to be involved in the occurrence of gastric cancer [26]. Our results showed rBMP-2 exerted inhibited effect on the proliferation of normal gastric cells and gastric cancer cells, and this inhibition was concentration-dependent. With the increase of rBMP-2 concentration, the inhibition became more evident. In addition, with the prolongation of rBMP-2 treatment, the IR was reduced in BGC823 cells but increased in SGC7901 cells and GES-1 cells, which were consistent with previously reported [27]. The progression of cell 
cycle is regulated by several factors one of which is CDK. Our results showed rhBMP-2 treatment could reduce the CDK4 expression in gastric cancer cells. These findings indicate that rhBMP-2 may block the transition from G1 phase to $S$ phase via inhibiting CDK4 expression, which then suppresses the proliferation of gastric cancer cells.

The extracellular BMPs can be antagonized by some secretory proteins including Cerbarus, Dan, Germlin, Noggin, Chordin, Follistatin, etc. These proteins can bind to BMPs which blocks the binding of BMPs to their receptors. In addition, these proteins can also affect the distribution of BMPs [28]. Our findings suggested BMP-2 could inhibit the proliferation of gastric cancer cells and epithelial cells of normal gastric mucosa. Following BMP-2 treatment, the changes in CDK4 expression were consistent with findings in MTT assay, both of which demonstrated that BMP-2 can inhibit the proliferation of these cells. In the present study, Noggin was employed to treat gastric cancer cells and normal gastric cells. After treatment with Noggin, an inhibitor of BMP-2, MTT assay and immunohistochemistry consistently indicated that the cell growth was promoted. At $48 \mathrm{~h}$ after Noggin treatment, cells were harvested and results showed the proportion of BGC823 cells and SGC7901 cells in $\mathrm{S}$ phase was markedly increased. It is indicated that Noggin treatment can promote the DNA synthesis. That is, Noggin can promote the cell proliferation. Following BMP-2 treatment, flow cytometry showed the proportion of apoptotic cells remained unchanged. Noggin can promote the proliferation of gastric cancer cells. The promotion of cell proliferation theoretically serves as an inverse process of DNA degradation. Noggin could promote the proliferation of BGC823 cells within $24 \mathrm{~h}$ and this promotive effect became more evident with the increase of Noggin concentration. For SGC7901 cells and GES-1 cells, the proliferation increased with the increase of Noggin concentration within $48 \mathrm{~h}$. Additionally, the promotive effect of Noggin was the most obvious at $48 \mathrm{~h}$ after Noggin treatment, and the proliferation had a reducing trend with the prolongation of Noggin treatment. The proliferation of BGC823 cells was more evident than that of SGC7901 cells and GES-1 cells after Noggin treatment.

These findings suggest Noggin at a certain concentration can bind to BMP-2 which changes the BMP-2 expression and affects the influence of BMP-2 on the cell proliferation. When compared with well differentiated gastric cancer and normal gastric epithelial cells, the poorly differentiated gastric cancer cells are more sensitive to the changes in BMP-2 expression. This further confirms that down-regulation or loss of BMP-2 expression may affect the differentiation and proliferation of cells and the changes in BMP-2 expression might be related to the degree of cell differentiation. In addition, our findings also showed, when the Noggin concentration was $\leq 100$ $\mathrm{ng} / \mathrm{ml}$, the proliferation of cells did not increase with the increase of Noggin concentration, and the promotive effect of Noggin on the proliferation was independent of concentration when the Noggin concentration was $\geq 1000 \mathrm{ng} / \mathrm{ml}$. These findings suggest the Noggin concentration is linearly related to the proliferation of gastric cancer cells when the Noggin concentration is in a certain range. In addition, flow cytometry showed the proportion of BGC 823 cells and SGC7901 cells in the $S$ phase markedly raised after Noggin treatment but that in the G1 phase significantly reduced. This further demonstrates that the binding of Noggin to BMP-2 leads to the inability of BMP-2 to bind to corresponding receptors and Noggin treatment promotes the DNA synthesis and inhibit the proliferation of gastric cancer cells. After Noggin treatment, the CDK4 expression in BGC823 cells and SGC7901 cells was increased. These findings were contrary to those after BMP-2 treatment. This suggests endogenous BMP-2 may reduce the DNA synthesis via down-regulating CDK4 expression, which inhibits the proliferation of epithelial cells. However, this effect of BMP-2 can be antagonized by BMP-2 inhibitor. Additionally, exogenous BMP-2 can arrest cells in G1 phase through down-regulating CDK4 expression suppressing the cell proliferation. Noggin can antagonize not only the BMP-2 but other members in BMP family (BMP-4, BMP-7, BMP-13). Different BMPs exert different effects, and thus, antagonizing other members of BMP family might be also attributed to the promotion of cell proliferation, which should be further confirmed in future studies.

Maloum et al applied Cre/LoxP recombinase system to knockout BMP-1a receptor in rats. Their results showed the parietal cells were reduced but the endocrine cells increased in the stomach [29]. This implies that the abnormality of BMP signaling pathway in the gastric mucosal cells may render BMPs unable to exert inhibited effect on the proliferation of endocrine cells, which might be related to the occurrence of gastric cancer. There is evidence showing that the serum BMP-2 level in gastric cancer patients was higher than in healthy controls, and gastric cancer patients with lymph node metastasis had higher BMP-2 level that those without lymph node metastasis [30, 31]. This finding suggests BMP-2 plays an important role in the occurrence of gastric cancer. Our results showed BMP-2 could inhibit the proliferation of gastric cancer in vitro. In gastric cancer patients, the 
BMP-2 signal transduction is abnormal, which reduces the suppressive effect of BMP-2 on cell proliferation and then compromises the anti-tumor effect of BMP-2. Thus, in future studies, the mechanisms underlying the abnormal BMP-2 signaling pathway, which may be helpful to elucidate the role of BMP-2 in the pathogenesis of gastric cancer.

There is evidence showing that TGF- $\beta$ can not only inhibit the growth of both normal gastric mucosal cells and gastric cancer cells but promote their apoptosis [32]. Study reveals that the apoptosis of smooth muscle cells in pulmonary artery is related to BMP [33], and BMP-4 can induce the apoptosis of oral mucosal epithelial cells in vitro [34]. However, our results did not confirm the pro-apoptotic effect of BMP-2 on gastric cancer cells, which may be attributed to low BMP-2 concentration or absence of involvement of BMP-2 in apoptosis of gastric mucosal cells. The specific mechanism is required to be further clarified.

Taken together, our findings primarily demonstrate that BMP-2 can inhibit the CDK4 expression in gastric cancer cells and block the transition from G1 phase into $S$ phase, which then inhibit the proliferation of gastric cancer. These findings suggest BMP-2 plays important roles in the occurrence and development of gastric cancer. Our results provide novel clues for the diagnosis and treatment of gastric mucosal diseases and gastric cancer.

\section{Acknowledgements}

This work was supported by the National Natural Science Foundation of China (30470793 and 30570846) and Science and Technology Development Fund of Shanghai Committee of Science and Technology (044119647).

\section{Conflict of Interest}

The authors have declared that no conflict of interest exists.

\section{References}

1. Achyut BR, Yang L. Transforming Growth Factor- $\beta$ in the Gastrointestinal and Hepatic Tumor Microenvironment. Gastroenterology. 2011;141(4):1167-78.

2. Cao $X, C h e n D$. The BMP signaling and in vivo bone formation. Gene. 2005;357(1):1-8.

3. Derynck R, Zhang Y, Feng XH. Smads: transcriptional activators of TGF-beta responses. Cell. 1998; 95(6):737-40.

4. Hoodless PA, Haerry T, Abdollah S, Stapleton M, O'Connor MB,Attisano L, et al. MADR1, a MAD-related protein that functions in BMP2 signaling pathways. Cell. 1996;85(4):489-500.

5. Fiocchi C. TGF-beta/Smad signaling defects in inflammatory bowel disease:Mechanisms and possible novel therapies for chronic inflammation. J Clin Invest, 2001;108(4):523-526.
6. De Caestecker M. The transforming growth factor- $\$$ superfamily of receptors. Cytokine Growth Factor Rev, 2004; 15: 1-11.

7. Derynck R, Zhang YE. Smad-dependent and Smad-independent pathways in TGF-beta family signaling. Nature, 2003; 425: 577-584.

8. Leedham SJ, Brittan M, Mcdonald SAC, et al. Intestinal stem cell. Cell Mol Med, 2005; 9(1): 11-24.

9. Hardwick JC, Van Den Brink GR, Bleuming SA, et al. Bone morphogenetic protein 2 is expressed by, and acts upon, mature epithelial cells in the colon. Gastroenterology, 2004;126(1): 111-121.

10. Hallahan AR, Pritchard JI, Chandraratna RA, Ellenbogen RG, Geyer JR, Overland RP, et al. BMP-2 mediates retinoid-induced apoptosis in medulloblastoma cells through a paracrine effect. Nat Med, 2003;9(8):1033-8.

11. Kawamura C, Kizaki M, Ikeda Y. Bone morphogenetic protein (BMP)-2 induces apoptosis in human myeloma cells. Leuk Lymphoma, 2002; 43(3):635-9.

12. Kim IY, Lee DH, Lee DK, Kim BC, Kim HT, Leach FS, et al. Decreased expression of bone morphogenetic protein (BMP) receptor type II correlates with insensitivity to BMP-6 in human renal cell carcinoma cells. Clin Cancer Res. 2003; 9(16 Pt 1):6046-51.

13. Langenfeld EM, Kong Y, Langenfeld J. Bone morphogenetic protein 2 stimulation of tumor growth involves the activation of Smad-1/5. Oncogene. 2006; 25(5):685-92.

14. Yang S, Zhong C, Frenkel B, Reddi AH, Roy-Burman P. Diverse biological effect and Smad signaling of bone morphogenetic protein 7 in prostate tumor cells. Cancer Res. 2005; 65(13):5769-77.

15. Feeley BT, Krenek L, Liu N, Hsu WK, Gamradt SC, Schwarz $\mathrm{EM}$, et al. Overexpression of noggin inhibits BMP-mediated growth of osteolytic prostate cancer lesions. Bone. 2006; 38(2):154-66.

16. Rothhammer T, Poser I, Soncin F, Bataille F, Moser M, Bosserhoff AK. Bone morphogenic proteins are overexpressed in malignant melanoma and promote cell invasion and migration. Cancer Res. 2005; 65(2):448-56.

17. Kim IY, Kim SJ. Role of bone morphogenetic proteins in transitional cell carcinoma cells. Cancer Lett. 2006;241(1):118-23.

18. Masuda H, Fukabori Y, Nakano K, Takezawa Y, CS T, Yamanaka $\mathrm{H}$. Increased expression of bone morphogenetic protein-7 in bone metastatic prostate cancer. Prostate. 2003; 54(4):268-74.

19. Aoki M, Ishigami S, Uenosono $Y$, et al. Expression of BMP-7 in human gastric cancer and its clinical significance. Br J Cancer, 2011; 104:714-718.

20. Katoh M, Terada M. Overexpression of bone morphogenic protein (BMP)-4 mRNA in gastric cancer cell lines of poorly differentiated type. Gastroenterology, 1996; 13: 1137-1139.

21. Kim SG, Park HR, Min SK, Choi JY, Koh SH, Kim JW, Lee HW. Expression of bone morphogenic protein- 4 is inversely related to prevalence of lymph node metastasis in gastric adenocarcinoma. Surg Today. 2011; 41(5):688-92.

22. Xu YX, Wang ZR, Tang RY, et al. Expressions and significance of BMP-2 and 4 in gastric mucosal diseases. Chin J Dig Endo, 2005; 22: 394-397.

23. Zhang YQ, Wang ZR, Chen XM, et al. Expression of BMP-2 and its significance in colorectal cancer. Chin J Dig Endo, 2007; 24: 365-367.

24. Li H, Du P, Xing GL, et al. Renoprotective effect of sodium ferulate on rats with 5/6 nephrectomy. China J Mod Med, 2005; 15:973-977.

25. Huang SS, Leal SM, Chen CL, et al. Cellular growth inhibition by TGF-beta involves IRS proteins. FEBS Lett, 2004; 565: 117-121. 
26. Oshima H, Oguma K, Du YC, et al. Prostaglandin E2, Wnt, and BMP in gastric tumor mouse models. Cancer Sci, 2009; 100:1779-1785.

27. Wen XZ, Miyake S, Akiyama Y, et al. BMP-2 modulates the proliferation and differentiation of normal and cancerous gastric cells. Biochem Biophys Res Commun, 2004; 316: 100-106.

28. Canalis E, Economides AN, Gazzerro E. Bone morphogenetic proteins, their antagonists, and the skeleton. Endocr, 2003; 24(2):218-235.

29. Maloum F, Allaire JM, Gagne -Sansfacon J, et al. Epithelial BMP signaling is required for proper specification of epithelial cell lineages and gastric endocrine cells. Am J Physiol Gastrointest Liver Physiol, 2011; 300:G1065-1079.

30. Park Y, Kim JW, Kim EB, et al. The bone morphogenesis protein-2 is associated with progression to metastatic disease in gastric cancer. Cancer Res Treat, 2008; 40:127-132.

31. Park Y, Kang MH, Seo HY, et al. Bone morphogenetic protein-2 levels are elevated in the patients with gastric cancer and correlate with disease progression. Med Oncol, 2010; 27:1192-1199.

32. Massague J, Blain SW, Lo RS. TGF-beta signaling in growth control, cancer and heritable disorders. Cell, 2000; 103: 295-309.

33. Lagna G, Nguyen PH, Ni W, et al. BMP-dependent activation of caspase- 9 and caspase- 8 mediates apoptosis in pulmonary artery smooth muscle cells. Am J Physiol Lung Cell Mol Physiol, 2006; 291: 1059-1067.

34 Kim SG, Chae CH, Cho BO, et al. Apoptosis of oral epithelial cells in oral lichen planus caused by upregulation of BMP-4. J Oral Pathol Med, 2006; 35: 37-45. 